\title{
ADVANCED ENERGY MANAGEMENT APPROACH IN FOOD INDUSTRY
}

Milena Rajić ${ }^{*}$, Pedja Milosavljević1 ${ }^{1}$ Rado Maksimović², Dragan Pavlović ${ }^{1}$

${ }^{1}$ Department of Management in Mechanical Engineering, Faculty of Mechanical Engineering, University of Nis, Niš, Serbia

2Department of Industrial Engineering and Management, Faculty of Technical Sciences, University of Novi Sad,, Novi Sad, Serbia

Energy represents a key aspect that characterizes the ability of an enterprise to maintain its sustainable business. It is also considered as a key resource, while its consumption should be monitored and controlled. The standard for the energy management system used widely in industry is ISO 50001. This standard specifies the requirements for the energy management system by introducing the material and the energy flow analysis. This paper presents the application of the energy management approach to identify the energy profile of the enterprise in the food industry sector. The energy flow was identified in order to have full insight into all energy consumption users. Based on the measured and calculated results, the energy performance indicators were obtained and compared with similar processes in the food industry. The aim of the paper is to analyze the energy demand in a production enterprise, to have insight into the material and energy flows in the process in order to optimize the production process.
(ORIGINAL SCIENTIFIC PAPER)

UDC 005:620.9:664

DOI: $10.5937 /$ savteh2002048R

Keywords: energy management, energy performance indicator, food industry, material energy flow analyses

\section{Introduction}

The optimization of energy flows within the enterprise requires additional costs, but the energy consumption and proper energy management clearly defines the enterprises energy profile [1,2]. Improved energy performance of an enterprise can provide direct benefits to the enterprise itself, maximizing the diversity of energy sources, while reducing energy costs and the energy consumption [3-6]. It can be said with confidence that energy management is becoming an increasingly critical factor of the production. The

proper management of the energy consumption affects the competitiveness of organizations and their willingness and flexibility to adapt to an increasingly demanding market and ensure their survival [7-11]. Current energy management practices indicate that proper management of energy flows and their optimization have long-term benefits for the enterprises' operations, and represent effective indicators of profitability [12-14]. On the other side, there are enterprises that do not see the priority of the energy management application and that solve problems without any systematic approach to the problem [1]. The standard ISO 50001 [15] specifies the requirements for the establishment of energy management systems (EnMS). The purpose of the standard is to enable enterprises to establish the processes that are necessary to improve the energy performance. The energy performance includes energy efficiency, energy consumption and/or other indicator. The application of standards leads to a lower negative impact on the environment, but also lower costs related to the energy consumption. It can be applied and certified in any type of enterprise. While the ISO 50001 gives only a framework and defines general requirements, the application of requirements and its compliance is the enterprise's responsibility $[15,16]$. The experience shows that companies have difficulties in following the steps: the assessment of the initial situation due to the lack of data and information; missing focus on the key energy consumer and deriving improvement measures; the implementation of a continuous improvement process through a lack of employees' interaction. These single components must be integrated with the plan-do-check-act-cycle (PDCA) [15]. The introduced model for energy audit is based on the model given in standard ISO 50001 [15].

Material flow analysis (MFA) has becoming one of the most important instruments to achieve the environmental protection, as well as the sustainable development of the enterprises. Introducing the industrial ecology or the industrial metabolism paradigm [17-19] it is possible to analyze, simulate, as well as to optimize the multi-product system. The outcome of these results presents how simulation and optimization can be done as part of the material flow analysis.

The food industry sector is characterized as a non-energy intensive industry where energy consumption represents a small part of the total production costs. It is approximately considered to be 3\% [20-22]. But it also represents an important energy consumer due to the size of the industry sector and the amount of the electricity consumed [23-25].

The aim of this paper is to present a new advanced approach for the energy management model application in a production organization in the food industry sector, by using the energy performance indicator, as a part of the energy management system.

*Author address: Milena Rajić Department of Management in Mechanical Engineering, University of Niš, Faculty of Mechanical Engineering, Aleksandra Medvedeva 14, 18000 Niš, Serbia

E-mail: milena.rajic@masfak.ni.ac.rs

The manuscript received: Jun, 23, 2020.

Paper accepted: July, 30, 2020 


\section{Experimental}

To identify the energy flow model in the enterprise, the experimental procedure was conducted. The experimental energy audit was performed in order to identify the critical consumers, monthly consumption and enterprises' energy demand. The proposed model was used and presented in Fig.1. The data used for energy audit was the amount of energy consumed for 2018 on monthly level, as well as the energy demand for end users, types of fuel and production volume.

The model has four stages including: general material and energy flow analysis, hot spot identification, detailed process metering and modelling and improvement evaluation, as it is shown in Figure 1.

\section{Stages}
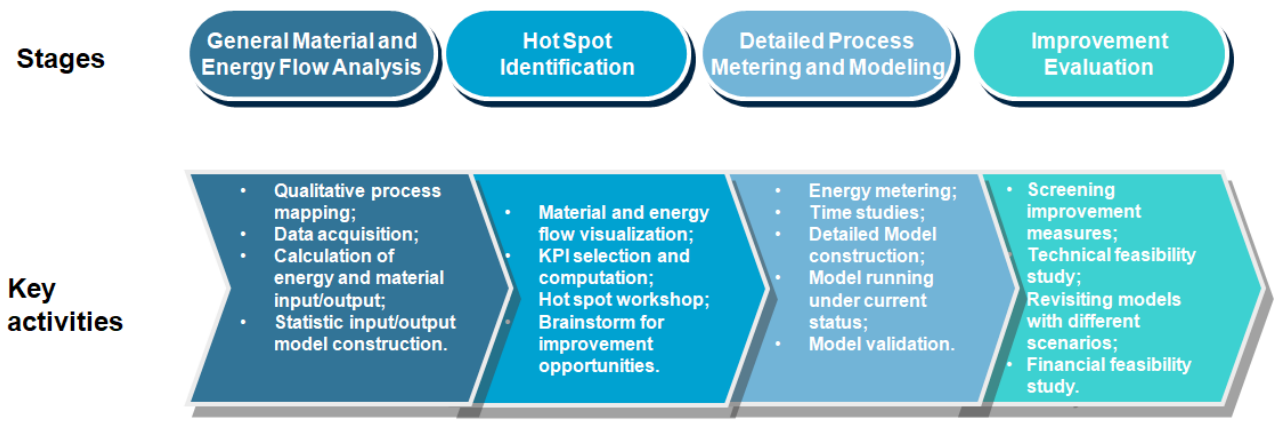

Figure 1. The proposed model for energy audit in the food sector

In stage 1, the first step is to define the system boundary and to list all included processes/machines. The energy and material flows can be qualitatively sketched by walking through site. The next step is to collect different types of data to quantify the flows, such as energy bills, machine specifications, material usage report, data regarding production wastes, production records etc. Due to the lack of the energy metering system, the most challenging task is to break down the energy consumption at the unit process level. However, a rough estimation of load factor can be made based on expert opinions, machine documentation, published energy profiles of similar processes, etc. In order to validate the estimation, the assumed load factors need to be reused for calculating different periods and compared with the energy bill. The comparison can be further used to adjust the assumptions for load factor. Finally, for the analysed period, the input as well as output flow can be quantified. In stage 2, the statistic results of collected data are recommended to be visualized in the form of Sankey diagram. The thickness of the arrows emphasizes the major energy and material flow to help to identify the "alarmed spots". Besides the total energy and material consumption, other key performance indicators need to be calculated in order to determine "the real" spot, where the further analysis should be. This leads to the next step: to organize a workshop involving the related engineers, operators and production planners to rank the identified hot spots of the plant and to generate ideas for improvement. Stage 3 refers to detailed process metering and modelling, which includes a sub-metering activity for a relatively short period of identified hot spots. In the meantime, a time study needs to be conducted to quantify the exact value adding time and non-value adding time. For the dynamic process, it is helpful to construct a more detailed process model, which can be further validated with metering results. The generic infor- mation obtained from stage 1 can be used to form the base line scenario. The last stage, stage 4 begins with screening improvement measures to select potential ones. It is necessary to review the detailed technical specifications and to compare with the limitations of the current process. A technical feasibility report can be generated, which includes all advantages or disadvantages of each option. Another step is revisiting models with different scenarios, in order to compare the total energy consumption and other process parameters directly. The potentials for energy savings can be also predicted relatively accurate. After obtaining the cost information of each option, the financial feasibility can be reported [26].

\section{Process approach}

In order to identify the energy flow within the production plan, it is necessary to have full insight into the production process. The analyzed enterprise includes processes in a mill and in a bakery. The bakery used electricity and furnace oil as an energy source. Electricity was used for the process machines in mills, bake ovens, cooling system and lightening, and furnace oil was used for bake ovens and boilers. The production process is presented in Figure 2. 


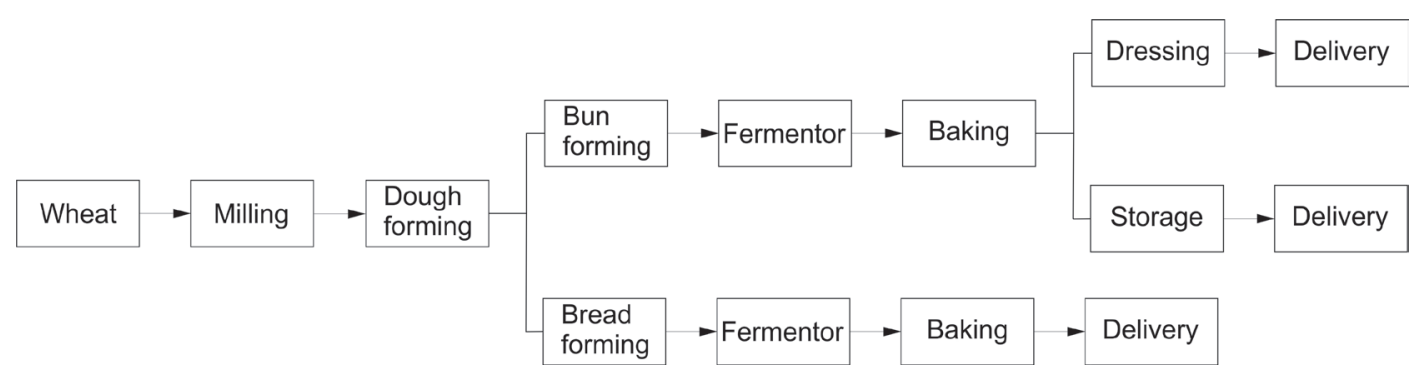

Figure 2. Production process diagram of the analyzed enterprise

The mill includes the process of flour milling and its storage in the silos, from where it is transported to the kneading machine by pneumatic system. Flour and other ingredients are mixed in the kneading machine and the dough is made for bread and for buns. Then the dough is formed into the bread and buns or rolled buns. The formed bread is fermented in the unit for fermentation and baked at 170-330 ${ }^{\circ} \mathrm{C}$. The dough bread is baked and then delivered to the customers. The bread moulds and baking trays are washed with hot water of approximately $35-40{ }^{\circ} \mathrm{C}$. On the other side, the bun dough is processed to the unit for fermentation, which is in a form of the storage room where the temperature is controlled automatically from -20 to $40^{\circ} \mathrm{C}$. Then, after $12-16 \mathrm{~h}$ the fermented bun dough is baked at 200-230 ${ }^{\circ} \mathrm{C}$. One part of the baked buns is stored in the cold room at the temperature of $-18-25{ }^{\circ} \mathrm{C}$ for the postponed delivery. The hot water boilers are used for hot water distribution, as well as space heating. The hot water $40^{\circ} \mathrm{C}$ was mainly used for washing the baking plates and dough moulds. The cold room and unit for fermentation are cooled by central absorption chiller.

\section{Energy profile}

The machines and units were listed in the production plant, in order to determine the energy profile of the enterprise. Based on the equipment rated power and the number of operating hours, the total energy consumption was calculated and compared with the previous analysis. The number of operating hours was calculated based on the evidence that is conducted by management. The limitations in identifying the number of effective operating hours were the cases where some equipment was working at different peak demand and time intervals during the operating hours.

To determine the energy profile of the enterprise, it is important to identify critical consumers and provide a detailed insight into how much energy is spent in the system that is not part of the production process, but represent a support such as: the system of central heating, cooling and ventilation, lightening, hot water sanitary heating, etc. By using the machine project and also the consumer identification on site, a list of the critical consumers with installed power was made. This data was used to present the consumers and their energy demand (Figure 3), as well as their electricity demand (Figure 4).

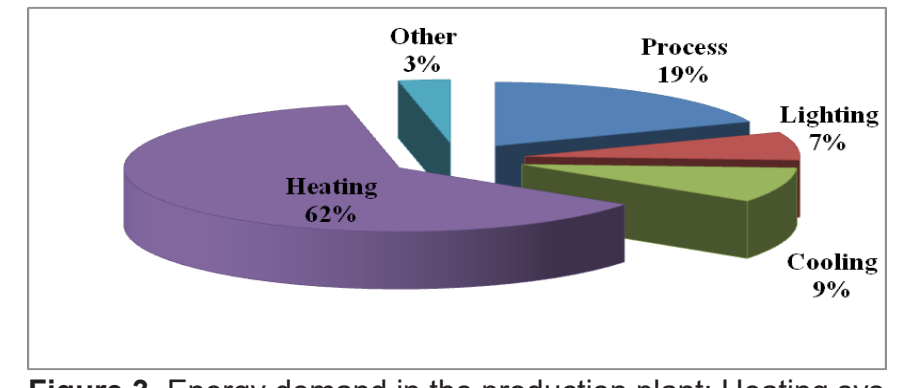

Figure 3. Energy demand in the production plant: Heating system of the production hall (62\% of the total energy demand), Lighting (7\%), Cooling System (9\%), Production process (19\%) and other consumers (about 3\%).

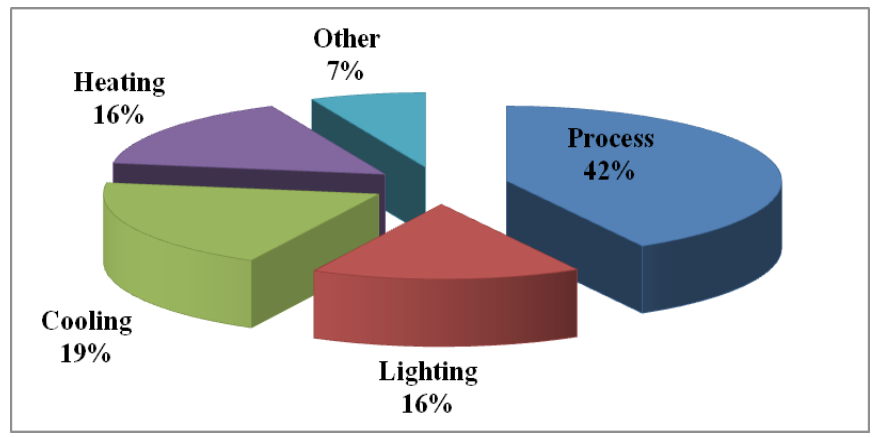

Figure 4. Electricity demand in the production plant: Heating system of the production hall (16\% of the total electricity demand), Lighting (16\%), Cooling System (19\%), Production process $(42 \%)$ and other consumers (about $7 \%$ ).

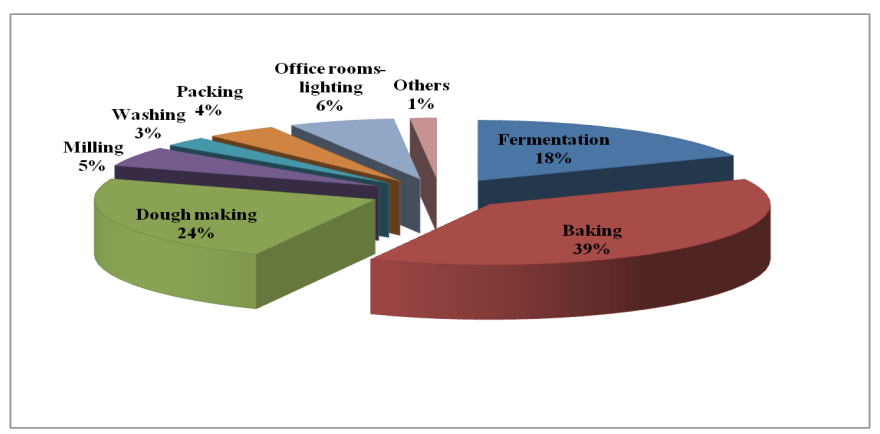

Figure 5. Consumers overview in the production plant and their electricity demand: Milling (5\% electricity demand), Dough making (24\%), Baking (39\%), Fermentation (18\%), Washing line $(3 \%)$, Packing (4\%), Office rooms/lighting (6\%), Other consumers $(1 \%)$. 
In order to identify the largest consumers, the critical machines and units are identified in the whole production hall. The graphical representation of the consumers is shown in Figure 5.

\section{Results and Discussion}

In order to present the main results, it is necessary to introduce the energy performance which represents the amount of actually consume in order to meet different needs of an enterprise. In an industrial process, it is defined as the realized consumption of energy and energy sources at the organization level in a certain period of time - a month or a business year. Based on the data on electricity consumption, an overview of the energy performance of the considered processed can be given $[27,28]$. For analysis, is necessary to define the concept of energy performance indicators. The energy performance indicators are defined as specific energy consumption at the organization level in a certain period of time - a month and a business year. Energy performance indicators are presented as a ratio:

$$
I P(t)=\frac{E(t)}{A(t)}
$$

where are:

$I P(t)$ - Energy performance indicator;

$E(t)$ - Amount of energy consumed;

$A(t)$ - Indicator of monitored activity for which energy is used (quantity of products/services, area of heated space and similar); $t$ - Period of time for which the energy performance indicator is calculated.

While the production process is mainly bakery, due to the data given in papers [29-31] for monitored activity indicator the amount of used/produced flour as a ratio is mostly used:

$$
I P(t)=\frac{E(t)}{F(t)}
$$

where:

$F(t)$ - Processed/Used/Produced flour in period of time for which the energy performance indicator is calculated

The data that is used for calculation is for 2018 , when the analysed bakery produced and used approximately 281 tons of flour. The specific energy consumption was presented on a weekly level for 2018 in Figure 6. Electricity consumption data on a weekly basis are not precisely given but adopted by using monthly consumption and the number of working hours in each week. Based on the data conducted, the lowest value of the indicator can be identified, when electricity is used minimally to reach the operational capacity. The critical moments can also be observed when consumption is higher than usual, in order to analyze the causes. This can provide insight into various accident conditions, working failures, break downs in the process, and also enable in a preventive way to avoid such conditions in the future.

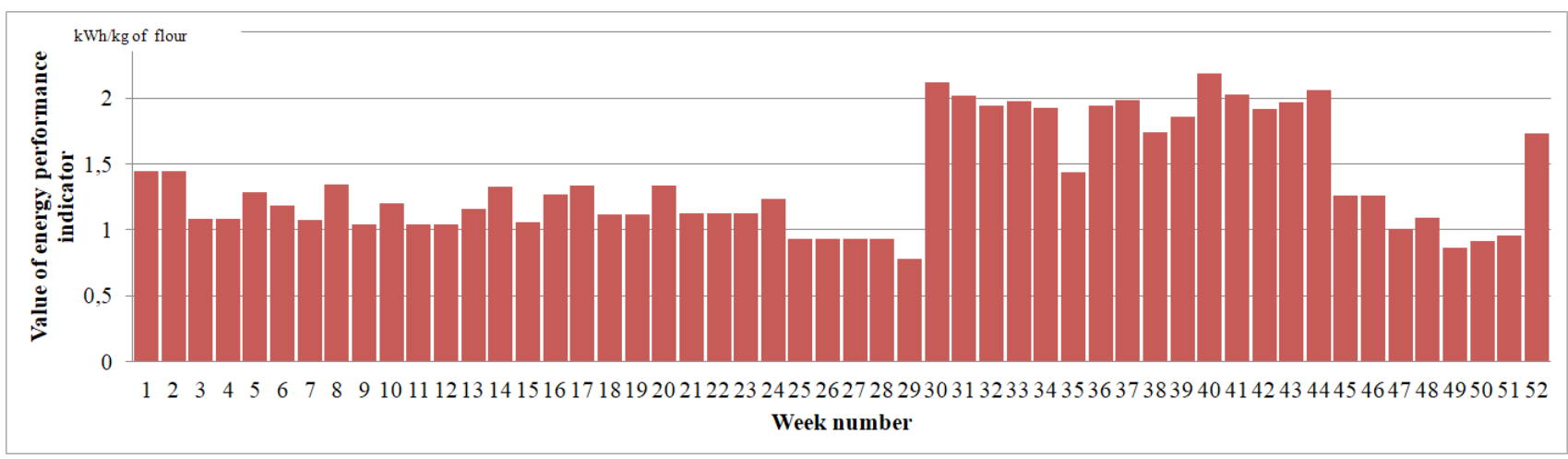

Figure 6. Energy performance indicators for the analysed enterprise

According to the calculated data, the minimal energy performance indicator was $0,7996 \mathrm{kWh} / \mathrm{kg}$ of flour and maximal 2,1889 $\mathrm{kWh} / \mathrm{kg}$ of used flour, and the average value was $1,3726 \mathrm{kWh} / \mathrm{kg}$ of flour. These data can be compared with the one from literature, where the energy performance indicator was $1,37 \mathrm{kWh} / \mathrm{kg}$ of flour [29] and the energy performance indicator is in the range of 1,27$1,89 \mathrm{kWh} / \mathrm{kg}$ of processed flour depending upon the type of the fuel used in the bake ovens [29-32]. With presented data, the analyzed process is in the range of the average energy performance indicator. Critical weeks should be noted (from 30 to 44 in 2018 in Figure 6), when the indicator was on the maximum level. The phase of monitoring the plant is necessary to be conducted in a certain period of time (once a year, two times a year) in order to keep track of the energy consumption and to evaluate the indicators to propose the energy saving measures [33]. This evaluation would enable to predict the energy consumption and to identify the new possibilities of the process optimization. 


\section{Conclusion}

The paper presents a case study of the energy management approach for the identification of energy flows within the production enterprise. A proper design of the material and energy flows represents the basis of sustainable production processes in order to have minimal resource wastes and loses, but also to provide a positive impact on the environment. The aim was to examine energy flows in the manufacturing sector and to identify the energy demand for such production in order to conduct the comparative analysis with similar production processes. The production processes in food industry sector is analyzed mostly by using the material flow, so the energy flow and energy consumption are usually negligible. Higher energy consumption is related to the process itself, but also to dynamic operations that should be planned, controlled and monitored. The presented approach of energy management model would be developed in the form to follow the patterns that are established in production processes, as well as to foreseen the consumption peaks and to provide sustain and reliable operation without any unnecessary energy losses.

\section{Acknowledgement}

This research was financially supported by the Ministry of Education, Science and Technological Development of the Republic of Serbia.

\section{References}

[1] V. Introna, V. Cesarotti, M. Benedetti, S. Biagiotti, R. Rotunno, Energy Management Maturity Model: An organizational tool to foster the continuous reduction of energy consumption in companies, Journal of Cleaner Production, 83 (2014) 108-117.

[2] A. Amundsen, Joint management of energy and environment, Journal of Cleaner Production, 8(6) (2000) 483-494.

[3] J. A. Laitner, An overview of the energy efficiency potential, Environmental Innovation and Societal Transitions, 9 (2013) 38-42.

[4] V. Dobes, New tool for promotion of energy management and cleaner production on no cure, no pay basis, Journal of Cleaner Production, 39 (2013) 255-264.

[5] M. Pye, A. McKane, Making a stronger case for industrial energy efficiency by quantifying non-energy benefits, Resources, Conservation and Recycling, 28(3-4) (2000) 171-183.

[6] K. Bunse, M. Vodicka, P. Schönsleben, M. Brülhart, F.O. Ernst, Integrating energy efficiency performance in production management - gap analysis between industrial needs and scientific literature, Journal of Cleaner Production, 19(6-7) (2011) 667-679.

[7] S. Thiede, G. Posselt, C. Herrmann, SME appropriate concept for continuously improving the energy and resource efficiency in manufacturing companies, CIRP Journal of Manufacturing Science and Technology, 6(3) (2013) 204-211.

[8] J. R. Duflou, J. W. Sutherland, D. Dornfeld, C. Herrmann,
J. Jeswiet, S. Kara, M. Hauschild, K. Kellens, Towards energy and resource efficient manufacturing: A processes and systems approach, CIRP Annals-Manufacturing Technology, 61(2) (2012) 587-609.

[9] S. Suh, Theory of materials and energy flow analysis in ecology and economics, Ecological modelling, 189(3) (2005) 251-269.

[10] S. Doty, W. Turner, Energy Management Handbook. The Fairmont Press, 2009.

[11] J. Beer, Potential for industrial energy-efficiency improvement in the long term, Eco-efficiency in industry and Science, Springer, 2000, Vol. 5.

[12] P. Ghadimi, W. Li, S. Kara, C. Herrmann, Integrated Material and Energy Flow Analysis towards Energy Efficient Manufacturing, 21st CIRP Conference on Life Cycle Engineering, Procedia CIRP, 15 (2014) 117 - 122.

[13] T. Fleiter, W. Eichhammer, J. Schleich, Energy efficiency in electric motor systems: Technical potentials and policy approaches for developing countries, United Nations Industrial Development Organization, 2011.

[14] R. Y. Yin, Metallurgical Process Engineering, Springer Heidelberg, ISBN 978-3-642-13955-0, 2011, New York, USA.

[15] International Organization for Standardization, 2011, ISO 50001:2011, Energy management systems Requirements with guidance for use, Genève, Switzerland, 2011.

[16] A. Herrero Sola, A. de Paula Xavier, Organizational human factors as barriers to energy efficiency in electrical motors systems in industry, Energy Policy, 35 (2007) 5784-5794.

[17] M. Fischer-Kowalski, Society's Metabolism - The Intellectual History of Material Flow Analysis, Part I, 1860 - 1970, Journal of Industrial Ecology, 2(1) (1998) 61-78.

[18] M. Fischer-Kowalski, W. Hüttler, Society's Metabolism The Intellectual History of Material Flow Analysis, Part II, 1970 - 1998, In Journal of Industrial Ecology 2(4) (1998) 107-136.

[19] A. Moeller, M. Prox, M. Schmidt, H. Lambrecht, Simulation and optimization of material and energy flow systems, Proceedings of the 2009 Winter Simulation Conference (WSC), (2009) 1444-1455.

[20] H. L. F. De Groot, E. T. Verhoef, P. Nijkamp, Energy savings by firms: decision-making, barriers and policies, Energy economics, 23(6) (2001) 717-740.

[21] P. Sandberg, M. Soderstrom, Industrial energy efficiency: the need for investment decision support from a manager perspective, Energy policy, 31(15) (2003) 1623-1634.

[22] D. C. A. Muller, F. M. A. Marechal, T. Wolewinski, P. J. Roux, An energy management method for the food industry, Applied Thermal Engineering, 27(16) (2007) 2677-2686.

[23] D. E. Hathaway, Food Prices and Inflation, Brookings Paperson Economic Activity, 1 (1974), 63-116.

[24] C. Wallgren, M. Hojer, Eating energy-identifying possibilities for reduced energy use in the future food supply system, Energy Policy 37 (2009) 5803-5813.

[25] C. M. Ma, M. H. Chen, G. B. Hong, Energy conservation status in Taiwanese food industry, Energy Policy 50 (2012) 458-463.

[26] P. Milosavljević, M. Rajić, R. Maksimović, D. Pavlović, M. Ferenčak, M. Leber, Material and Energy Flow in Industrial Environment, Material and Energy Flow in Industrial Environment, Proceedings of the 4th International Conference Mechanical Engineering in XXI Century, 
Faculty of Mechanical Engineering, April 19-20, 2018, Niš, Serbia, (2018) 523-526.

[27] N. Tasić, Ž. Đurić, D. Malešević, R. Maksimović, N. Radaković, Automation of Process Performance Management in a Company, Tehnicki vjesnik - Technical Gazette 25(2) (2018) 565-572.

[28] M. Rajić, The Model of the Energy Flow Management in Industrial Systems, PhD Thesis, (2020), University of Novi Sad, Faculty of Technical Sciences, Novi Sad, Serbia.

[29] R. Kannan, W. Boie, Energy management practices in SME-case study of a bakery in Germany, Energy Conversion and Management 44(6) (2003) 945-959.

[30] Energy Efficiency in a crisp-bread bakery. Centre for the Analysis and Dissemination of Demonstrated Energy Technologies (CADDET). Newsletter, 3 (2000) 4-5.
[31] Heat pipe saves energy in the baking industry. Centre for the Analysis and Dissemination of Demonstrated Energy Technologies (CADDET). Energy Efficiency brochure, Result 277 (1997).

[32] P. Thollander, S. Backlund, A. Trianni, E. Cagno, Beyond barriers - A case study on driving forces for improved energy efficiency in the foundry industries in Finland, France, Germany, Italy, Poland, Spain, and Sweden, Applied Energy 111 (2013) 636-643.

[33] P. Milosavljevic, M. Todorovic, D. Pavlovic, The Application of SCADA System in the Facility for Treatment and Preparation of Drinking Water, Journal of Advanced Technologies 2(1) (2013) 89-96.

Izvod

\section{SAVREMENI PRISTUP MENADŽMENTA ENERGIJOM U PREHRAMBENOJ INDUSTRIJI}

Milena Rajić ${ }^{1}$, Pedja Milosavljević ${ }^{1}$, Rado Maksimović , Dragan Pavlović1

${ }^{1}$ Katedra za menadžment u mašinskom inženjerstvu, Mašinski fakultet, NIš, Univerzitet u Nišu, Srbija

${ }^{2}$ Katedra za industrijsko inženjerstvo i menadžment, Fakultet tehničkih nauka, Univerzitet u Novom Sadu, Novi Sad, Srbija

Energija predstavlja ključan aspekt koji karakteriše poslovanje jedne kompanije. Može se smatrati i ključnim resursom, čija potrošnja bi trebalo biti nadgledana i kontrolisana. Standard za sistem upravljanja energijom koji se koristi u industriji je ISO 50001. Ovaj standard specificira zahteve za uspostavljanje sistema menadžmenta energijom uvodjenjem analize tokova materijala i energije. Ovaj rad predstavlja primenu pristupa menadžmenta energijom kako bi se utvrdio energetski profil kompanije u prehrambenom industrijskom sektoru. Identifikovan je tok energije kako bi se pružio potpun uvid u potrošnju energije svih potrošača u procesu. Na osnovu izmerenih i proračunatih rezultata, odredjeni su indikatori energetske performance i uporedjeni su sa sličnim procesima u prehrambenoj industriji. Cilj ovog rada je da se analizira energetska potreba u proizvodnoj kompaniji, da se utvrdi tok materijala i energije kako bi se optimizovao proizvodni process.
(ORIGINALNI NAUČNI RAD) UDK 005:620.9:664 DOI: $10.5937 /$ savteh2002048R

Ključne reči: menadžment energijom, indicator energetske performanse, prehrambena industrija, analiza tokova materijala i energije 